Supplement of Biogeosciences, 18, 5555-5571, 2021 https://doi.org/10.5194/bg-18-5555-2021-supplement (C) Author(s) 2021. CC BY 4.0 License.

(c) (1)

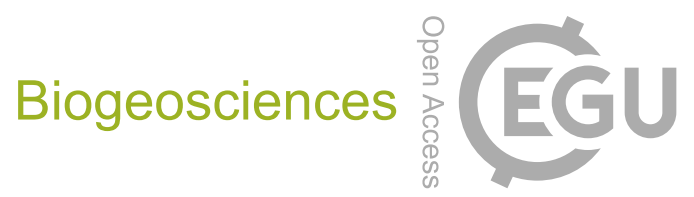

Supplement of

\title{
Exploring the use of compound-specific carbon isotopes as a palaeoproductivity proxy off the coast of Adélie Land, East Antarctica
}

Kate E. Ashley et al.

Correspondence to: James Bendle (j.bendle@bham.ac.uk)

The copyright of individual parts of the supplement might differ from the article licence. 


\section{S1. Core description and chronology}

Sediment core DTGC2011 (66 $24.50^{\circ} \mathrm{S}$ - 140²6.43'E, $1030 \mathrm{~m}$ water depth, $4.69 \mathrm{~m}$ gravity core) was recovered from the Dumont D’Urville Trough off the Adélie Land Coast, East Antarctica, aboard the R/V Astrolabe during the 2011 ALBION-HOLOCLIP cruise. The sediment is composed of diatom ooze and presents a laminated to banded structure throughout the entire sequence as revealed by positive X-ray images. The succession of dark and light laminations respectively represents the summer and spring seasons. High phytoplankton productivity during spring results in the deposition of greenish and light laminations while less organic-rich sedimentation during summer/autumn results in the preservation of dark and dense laminations (Maddison et al., 2012).

The chronology of core DTGC2011 is based on radiocarbon dates and confirmed by ${ }^{210} \mathrm{~Pb}$ excess activity measurements $\left({ }^{210} \mathrm{~Pb}_{\mathrm{xs}} ; \mathrm{T}_{1 / 2}=22,3\right.$ years $)$ which is rapidly incorporated into the sediment from atmospheric fallout and water column scavenging. ${ }^{210} \mathrm{~Pb}_{\mathrm{xs}}$ analyses were performed on the first meter of core DTGC2011 until detection was too low to be representative (Fig S1b). The activities of ${ }^{210} \mathrm{~Pb}$ and ${ }^{226} \mathrm{Ra}$ were measured on dried sediments by non-destructive gamma spectrometry using a well-type, high efficiency low-background detector equipped with a Cryo-cycle (CANBERRA). Activities are expressed in $\mathrm{mBq} \cdot \mathrm{g}^{-1}$ and errors are based on 1 s.d. counting statistics (Fig. S1C). ${ }^{210} \mathrm{~Pb}$ xs was determined by subtracting the activity supported by its parent isotope, ${ }^{226} \mathrm{Ra}$, from the total ${ }^{210} \mathrm{~Pb}$ activity in the sediment. The ${ }^{210} \mathrm{~Pb}$ xs activity of $\sim 160 \mathrm{mBq} \cdot \mathrm{g}^{-1}$ measured in DTGC2011 core-top is slightly lower than the activity of $\sim 225 \mathrm{mBq} \cdot \mathrm{g}^{-1}$ measured in the first half-centimetre of the twin interface core DTCI2010, that preserved the interface (Campagne et al., 2016). This suggests that core DTGC2011 lost the top few centimetres. By applying the decay law to the top ${ }^{210} \mathrm{~Pb}_{\mathrm{xs}}$ activities of each core, we estimate the age of the top DTGC2011 to be around 1997. The exponential decrease of sedimentary ${ }^{210} \mathrm{~Pb}_{\mathrm{xs}}$ activities in DTGC2011 was used to calculate a mean sedimentation accumulation rate of $\sim 1.2 \mathrm{~cm}$. $\mathrm{yr}^{-1}$, by applying the constant flux / constant sedimentation (CF/CS) model. The deposition time (in years) was obtained by dividing the depth of each layer by the sediment accumulation rate and by assuming an age of 1997 at the top core. This yields a bottom age of $\sim 1610$ C.E. when linearly extrapolated over the whole core using the equation presented in Fig. 2B.

Acid insoluble organic matter (AIOM) radiocarbon dates were performed at five depths in core DTGC2011 and were complemented by one AIOM radiocarbon date in the core-top of the twin interface core DTCI2010 plus one AIOM radiocarbon date in a deep sediment trap moored at the same location and retrieved during the same cruise (Table 1). All dates were performed at the Center for Accelarator Mass Spectrometry from the Lawrence Livermore National Laboratory, USA. DTGC2011 core-top date was discarded due to a very large inversion value. DTGC2011 core-top age was therefore estimated from the dates obtained in DTCI2010 core-top and in the deep sediment trap, both of them providing a similar ${ }^{14} \mathrm{C}$ age of 1735 years for recently buried material. The raw dates were calibrated with CALIB7.02 software using the Marine 13 calibration curve (Reimer et al., 2013) after applying a total correction of $1625 \pm 100$ years, which includes the local reservoir age of $1200 \pm 100$ years 
(Ingølfsson et al., 1998) and the local dead carbon fraction of 425 years (Costa et al., 2007 and references cited therein) as recommended for the area. This approach could not reconcile DTGC2011 core-top radiocarbon calibrated age with the ${ }^{210} \mathrm{~Pb}_{\mathrm{xs}}$ inferred age, suggesting that the dead carbon fraction of 425 years, averaged over Holocene sediment sequences, is not appropriate for the most recent sediments. An additional dead carbon fraction correction of 208 years was then applied to all calibrated dates. The depth-age conversion was achieved through a linear regression on the five control points (between $0 \mathrm{~cm}$ and $409 \mathrm{~cm}$ ), therefore allowing to extrapolate ages down to $469 \mathrm{~cm}$. As a result, core DTGC2011 spans the 1580-2000 C.E. period with a mean sedimentation rate of $\sim 1 \mathrm{~cm} . \mathrm{yr}^{-1}$.

Both ${ }^{14} \mathrm{C}_{\text {and }}{ }^{210} \mathrm{~Pb}$ xs methods infer very similar depth-age relationships, with a maximum difference of thirty years at the core bottom. We chose to use the radiocarbon chronology as the ${ }^{14} \mathrm{C}$ approach provides a control over 409 $\mathrm{cm}$ as compare to $100 \mathrm{~cm}$ for the ${ }^{210} \mathrm{~Pb}_{\mathrm{xs}}$ approach.

Table S1: List of AMS 14C samples and detail of the calibration process to develop core DTGC2011 age model.

\begin{tabular}{|c|c|c|c|c|c|c|c|c|}
\hline Provenance & $\begin{array}{l}\text { Depth } \\
(\mathrm{cm})\end{array}$ & $\begin{array}{l}\text { Raw 14C age } \\
\text { (years) }\end{array}$ & $\begin{array}{l}\begin{array}{l}\text { Reservoir age } \\
\text { (years) }\end{array} \\
\end{array}$ & $\begin{array}{l}\text { Calibrated age }-1 \mathrm{~s} \\
\text { (years B.P.) }\end{array}$ & $\begin{array}{l}\text { Mean age } \\
\text { (Years B.P.) }\end{array}$ & $\begin{array}{l}\text { Mean age } \\
\text { (Years C.E.) }\end{array}$ & $\begin{array}{l}\text { Correction to } 2010 \\
\text { (Years) }\end{array}$ & $\begin{array}{l}\text { Final age } \\
\text { (Years C.E.) }\end{array}$ \\
\hline SED TRAP LOW & & $1735 \pm 35$ & $1200 \pm 100$ & $54-242$ & 148 & 1802 & 208 & 2010 \\
\hline DTCI2010 & $0-0,5$ & $1735 \pm 30$ & $1200 \pm 100$ & $54-242$ & 148 & 1802 & 208 & 2010 \\
\hline DTGC2011 & $0-0,5$ & $8145 \pm 40$ & $1200 \pm 100$ & $7415-7595$ & & & & \\
\hline DTGC2011 & $142-143$ & $1835 \pm 35$ & $1200 \pm 100$ & $122-374$ & 248 & 1702 & & 1910 \\
\hline DTGC2011 & $204-205$ & $2025 \pm 35$ & $1200 \pm 100$ & $321-505$ & 413 & 1537 & & 1745 \\
\hline DTGC2011 & $359-360$ & $2070 \pm 30$ & $1200 \pm 100$ & $359-548$ & 453,5 & 1496,5 & & 1704,5 \\
\hline DTGC2011 & $409-410$ & $2125 \pm 30$ & $1200 \pm 100$ & $440-614$ & 527 & 1423 & & 1631 \\
\hline
\end{tabular}



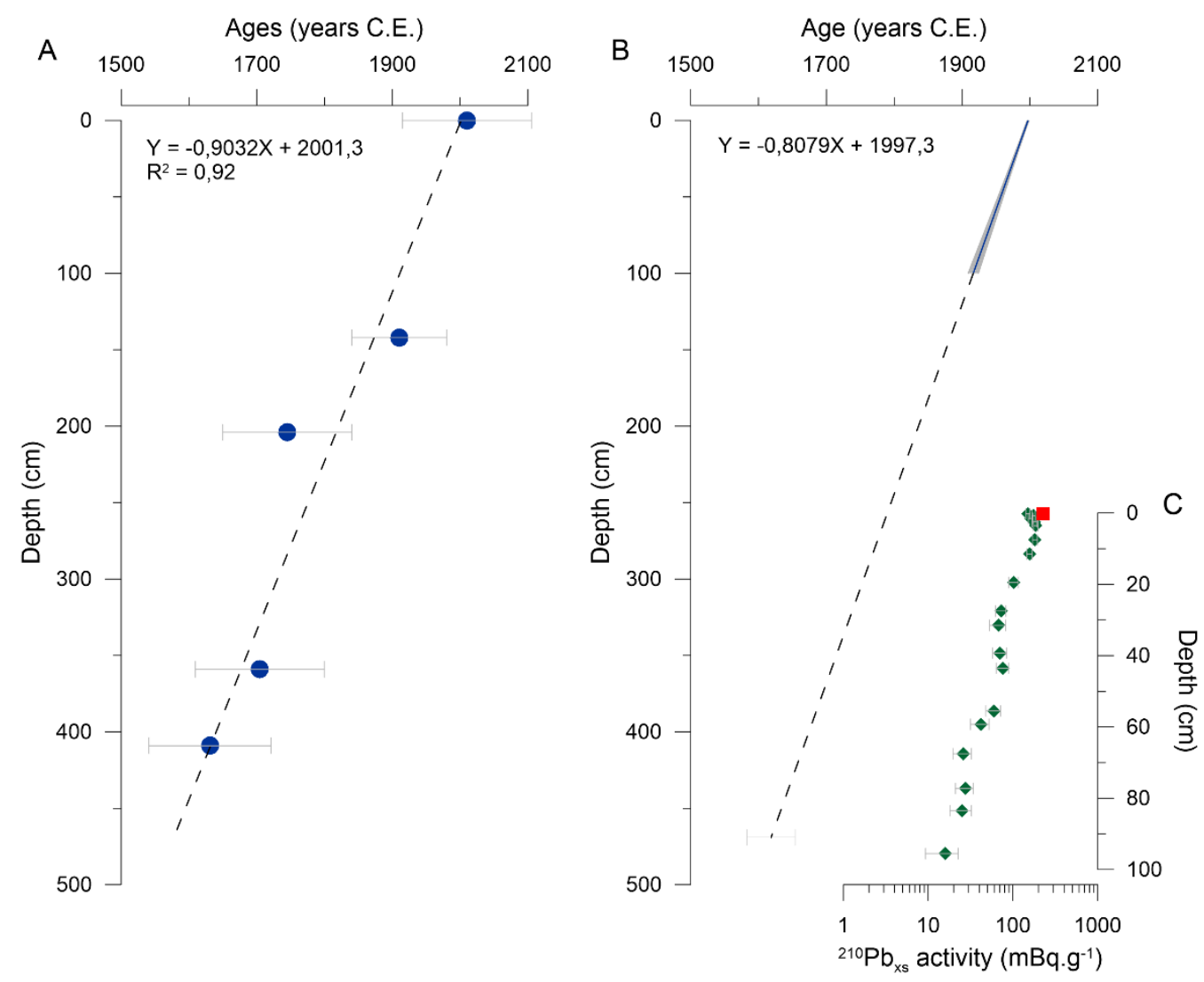

Figure S1: Chronology of core DTGC2011 based on AMS ${ }^{14} \mathrm{C}$ dates on AIOM, controlled by ${ }^{210} \mathrm{~Pb}_{\mathrm{xs} .}$ (A)

Corrected and calibrated ${ }^{14} \mathrm{C}$ mean ages in years C.E. (blue points) along with their $1 \mathrm{~s}$ range (horizontal bars) and the linear regression (dashed line) through the control points to extrapolate ages down to $469 \mathrm{~cm}$. (B) ${ }^{210} \mathrm{~Pb}_{\mathrm{xs}}$ inferred ages in years C.E. over the first meter along with the $1 \mathrm{~s}$ error (grey envelope) and the linear regression (dashed line) through the first meter depth-age values to extrapolate ages down to $469 \mathrm{~cm}$. (C) ${ }^{210} \mathrm{~Pb}_{\mathrm{xs}}$ activities in core DTGC2011 (green dots) and in the uppermost sample of the interface core DTCI2010 (red square) used to infer the sedimentation rate and ages over the first meter of the core. 
S2. Fatty acid chromatography
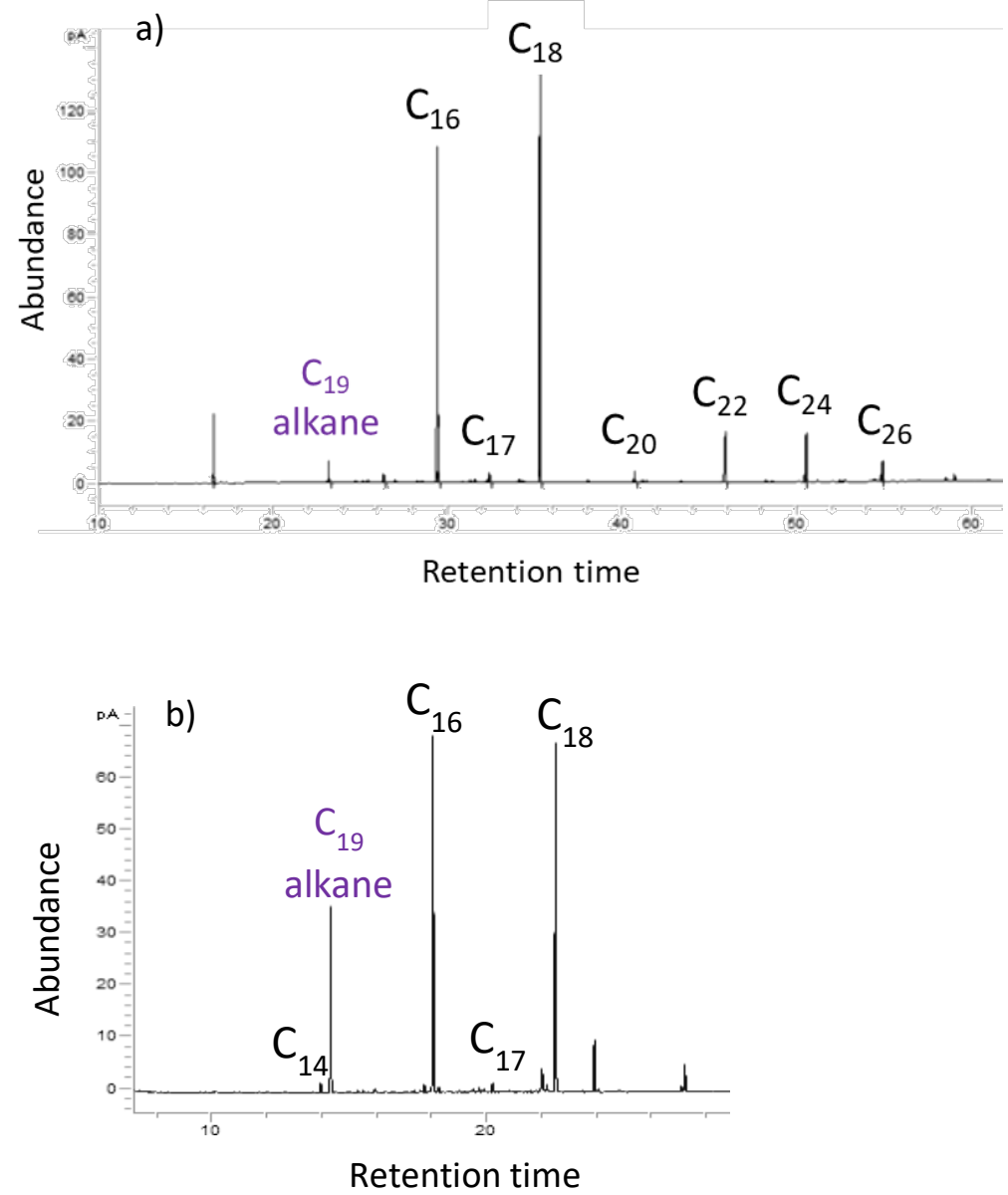

Figure S2: Typical chromatograms of the fatty acid fraction of DTGC2011 samples. Fatty acids are labelled according to their carbon number. An internal standard $\left(\mathbf{C}_{19}\right.$ alkane), which was used for quantification of fatty acids, is labelled in purple.

Chromatogram a) shows the whole suit of fatty acids present within samples, b) shows a small $C_{14}$ peak in relation to the $C_{19}$ alkane. 


\section{S3. Sources of long-chain fatty acids.}

Table S2: Summary of several studies where long-chain fatty acids have been shown to be produced by aquatic organisms.
Study
Fatty Acids
Aquatic
Contribution (\%)

Location

Source

\begin{tabular}{|c|c|c|c|c|}
\hline $\begin{array}{c}\text { Dalsgaard, J., et al. } \\
\text { (2003) }\end{array}$ & $\mathrm{C}_{14}-\mathrm{C}_{22}$ & $\mathrm{n} / \mathrm{a}$ & Meta-study & $\begin{array}{l}\text { Various planktonic } \\
\text { groups }\end{array}$ \\
\hline $\begin{array}{c}\text { Naraoka and } \\
\text { Ishiwatari (2000) }\end{array}$ & $\mathrm{C}_{20}-\mathrm{C}_{30}$ & $\begin{array}{c}\sim 38(\mathrm{C} 30)-88 \\
(\mathrm{C} 20)\end{array}$ & Northwest Pacific & Unknown \\
\hline $\begin{array}{l}\text { Holland et al. } \\
\text { (2013) }\end{array}$ & $\mathrm{C}_{24}-\mathrm{C}_{28}$ & $\mathrm{n} / \mathrm{a}$ & Lake El'gygytgyn, Russia & Unknown \\
\hline $\begin{array}{l}\text { Volkman et al. } \\
\qquad(1980)\end{array}$ & $\mathrm{C}_{24}-\mathrm{C}_{28}$ & $30-80$ & Victoria, Australia, intertidal & Diatoms \\
\hline $\begin{array}{l}\text { Schouten et al. } \\
\text { (1998) }\end{array}$ & $\mathrm{C}_{28}$ & $\mathrm{n} / \mathrm{a}$ & Culture & $\begin{array}{c}\text { Scenedesmus communis } \\
\text { (freshwater algae) }\end{array}$ \\
\hline Yunker et al. (2005) & $\mathrm{C}_{20}-\mathrm{C}_{28}$ & $46-66$ & Arctic Ocean & Algae \\
\hline $\begin{array}{c}\text { Rogerson and Johns } \\
\text { (1996) }\end{array}$ & $\mathrm{C}_{20}-\mathrm{C}_{28}$ & 100 & $\begin{array}{l}\text { Organic Lake, Antarctica } \\
\text { (hypersaline, meromictic) }\end{array}$ & Bacteria \\
\hline $\begin{array}{l}\text { Lawson et al. } \\
\text { (1986) }\end{array}$ & $\mathrm{C}_{24}-\mathrm{C}_{30}$ & 100 & $\begin{array}{c}\text { Westmere Reef, Auckland, } \\
\text { New Zealand }\end{array}$ & $\begin{array}{l}\text { Halichondria moorei } \\
\text { (marine sponge) }\end{array}$ \\
\hline \multirow{3}{*}{$\begin{array}{l}\text { Koopmans et al. } \\
\text { (2014) }\end{array}$} & \multirow{3}{*}{$\mathrm{C}_{24}-\mathrm{C}_{30}$} & \multirow{3}{*}{100} & $\begin{array}{c}\text { The Oosterschelde Estuary, } \\
\text { Netherlands }\end{array}$ & $\begin{array}{c}\text { Haliclona oculta and } \\
\text { Haliclona xena (marine } \\
\text { sponges) }\end{array}$ \\
\hline & & & Lake Veere, Netherlands & $\begin{array}{c}\text { Halichondria panacea } \\
\text { and Haliclona xena } \\
\text { (marine sponges) }\end{array}$ \\
\hline & & & $\begin{array}{c}\text { Northwest Mediterranean, } \\
\text { Spain }\end{array}$ & $\begin{array}{c}\text { Dysidea avara and } \\
\text { Aplysina aerophoba } \\
\text { (marine sponges) }\end{array}$ \\
\hline Viso et al. (1993) & $\mathrm{C}_{22}-\mathrm{C}_{34}$ & 100 & $\begin{array}{l}\text { Mediterranean coasts of } \\
\text { France and Greece }\end{array}$ & $\begin{array}{c}\text { Posidonia oceanica } \\
\text { (seagrass) }\end{array}$ \\
\hline $\begin{array}{c}\text { Leblond and } \\
\text { Chapman (2000) }\end{array}$ & $\begin{array}{l}\mathrm{C}_{20}-\mathrm{C}_{22}, \\
\text { trace } \mathrm{C}_{24}\end{array}$ & 100 & Culture & $\begin{array}{c}\text { Various dinoflagellate } \\
\text { species }\end{array}$ \\
\hline Allen et al. (2002) & $\mathrm{C}_{20}-\mathrm{C}_{22}$ & $\mathrm{n} / \mathrm{a}$ & Culture & $\begin{array}{l}\text { Marine gamma- } \\
\text { proteobacteria }\end{array}$ \\
\hline Allen et al. (1999) & $\mathrm{C}_{12}-\mathrm{C}_{20}$ & $\mathrm{n} / \mathrm{a}$ & Culture & P. profundum bacteria \\
\hline $\begin{array}{c}\text { Jónasdóttir, S. H. } \\
\text { (2019) }\end{array}$ & $\mathrm{C}_{14-\mathrm{C}_{22}}$ & various & Meta-study & $\begin{array}{c}\text { Various Marine } \\
\text { Phytoplankton groups }\end{array}$ \\
\hline
\end{tabular}




\section{References}

Allen, E. E. \& Bartlett, D. H. (2002), Structure and regulation of the omega-3 polyunsaturated fatty acid synthase genes from the deep-sea bacterium Photobacterium profundum strain SS9The GenBank accession numbers for the sequences reported in this paper are AF409100 and AF467805. Microbiology 148, pp. 19031913, doi: https://doi.org/10.1099/00221287-148-6-1903.

Allen, E. E., Facciotti, D. \& Bartlett, D. H. (1999), Monounsaturated but Not Polyunsaturated Fatty Acids Are Required for Growth of the Deep-Sea Bacterium Photobacterium profundum SS9 at High Pressure and Low Temperature. Applied and Environmental Microbiology 65, 1710-1720, doi:10.1128/aem.65.4.1710-1720.1999.

Campagne, P., et al. (2016) Sedimentary response to sea ice and atmospheric variability over the instrumental period off Adélie Land, East Antarctica, Biogeosciences, 13(14), pp. 4205-4218. doi: 10.5194/bg-13-42052016.

Costa, E., Dunbar, R. B., Kryc, K.A. et al. (2007) Solar forcing and El Nino-Southern Oscillation (ENSO) influences on productivity cycles interpreted from a late-Holocene high-resolution marine sediment record, Adélie Drift, East Antarctic margin', Open-File Report - U. S. Geological Survey, p. Short Research Paper 036. doi: 10.3133/of2007-1047.srp036.

Dalsgaard, J., St. John, M., Kattner, G., et al. (2003) Fatty acid trophic markers in the pelagic marine environment. Advances in Marine Biology. 46 pp. 225-340. doi:10.1016/S0065-2881(03)46005-7.

Holland, A.R., Petsch, S.T., Castañeda, I.S., et al. (2013) A biomarker record of Lake El'gygytgyn, Far East Russian arctic: Investigating sources of organic matter and carbon cycling during marine isotope stages 1-3. Climate of the Past, 9 (1): 243-260. doi:10.5194/cp-9-243-2013.

Ingólfsson, Ó, Hjort, C., Berkman, P., Björck, S., Colhoun, E., Goodwin, I., et al. (1998). Antarctic glacial history since the Last Glacial Maximum: An overview of the record on land. Antarctic Science, 10(3), 326-344. doi:10.1017/S095410209800039X

Jónasdóttir, S. H. Fatty Acid Profiles and Production in Marine Phytoplankton. Marine Drugs 17, 151 (2019).

Koopmans, M., van Rijswijk, P., Boschker, H.T.S., et al. (2014) Seasonal Variation of Fatty Acids and Stable Carbon Isotopes in Sponges as Indicators for Nutrition: Biomarkers in Sponges Identified. Marine

Biotechnology, 17 (1): 43-54. doi:10.1007/s10126-014-9594-8.

Lawson, M.P., Bergquist, P.R. and Cambie, R.C. (1986) The cellular localization of long chain fatty acids in sponges. Tissue and Cell, 18 (1): 19-26. doi:10.1016/0040-8166(86)90004-2.

Leblond, J.D. and Chapman, P.J. (2000) LIPID CLASS DISTRIBUTION OF HIGHLY UNSATURATED LONG CHAIN FATTY ACIDS IN MARINE DINOFLAGELLATES. Journal of Phycology, 36: 1103-1108.

Maddison, E. J., Pike, J. and Dunbar, R. (2012) 'Seasonally laminated diatom-rich sediments from Dumont d'Urville Trough, East Antarctic Margin: Late-Holocene Neoglacial sea-ice conditions', The Holocene, 22(8), pp. 857-875. doi: 10.1177/0959683611434223. 
Naraoka, H. and Ishiwatari, R. (2000) Molecular and isotopic abundances of long-chain n-fatty acids in open marine sediments of the western North Pacific. Chemical Geology, 165 (1-2): 23-36. doi:10.1016/S00092541(99)00159-X.

Rogerson, J.H. and Johns, R.B. (1996) "A geolipid characterization of Organic Lake - A hypersaline meromictic Antarctic lake.” In Organic Geochemistry. 1996. pp. 1-8. doi:10.1016/S0146-6380(96)00109-X.

Schouten, S., Klein Breteler, W.C.., Blokker, P., et al. (1998) Biosynthetic effects on the stable carbon isotopic compositions of algal lipids: implications for deciphering the carbon isotopic biomarker record. Geochimica et Cosmochimica Acta, 62 (8): 1397-1406. doi:10.1016/S0016-7037(98)00076-3.

Viso, A.-C., Pesando, D., Bernard, P., et al. (1993) Lipid components of the mediterranean seagrass Posidonia Oceanica. Phytochemistry, 34 (2): 381-387. doi:10.1016/0031-9422(93)80012-H.

Volkman, J.K., Eglinton, G. and Corner, E.D.S. (1980) Sterols and fatty acids of the marine diatom biddulphia sinensis. Phytochemistry, 19 (8): 1809-1813. doi:10.1016/S0031-9422(00)83818-2.

Yunker, M.B., Belicka, L.L., Harvey, H.R., et al. (2005) Tracing the inputs and fate of marine and terrigenous organic matter in Arctic Ocean sediments: A multivariate analysis of lipid biomarkers. Deep-Sea Research Part II: Topical Studies in Oceanography, 52 (24-26): 3478-3508. doi:10.1016/j.dsr2.2005.09.008. 